\title{
Wine and Modernity in the Transylvanian Saxon Imagination (1860-1930)
}

\author{
SACHA DAVIS
}

University of Newcastle, New South Wales, Australia

Transylvanian Saxon writings on wine and viniculture provide unusually informative insights as to the small East European community's responses to the impacts of modernization: loss of corporate privileges, minority status in first Habsburg Hungary and after the First World War, Romania, and increasing integration into a global economy. Transylvanian Saxons imbued wine with symbolic functions beyond its dietary or economic importance; viniculture and wine embodied Saxon aspirations and fears for the future. While ethnographers invoked the traditions embodied in wine to shore up Saxon status within Transylvania, economists extolled viniculture as an industry capable of modernization and a secure financial future for the community. Conversely, Saxon abstinence campaigners identified wine as the root of the Saxons' decline, and hoped to build a better future through its abolition. Through its symbolic roles, wine and viniculture reveal the potentials and limitations the Transylvanian Saxon community faced in confronting modernization.

KEYWORDS viniculture, nationalism, landscape, ethnography, abstinence, eugenics

The aproximately 240,000-STrong Transylvanian SaXons had their origins in twelfth-century migrants from the Mosel-Rhineland region. ${ }^{\text {I }}$ Granted corporate privileges in return for settling in Transylvania, Saxons formed a privileged estate, the natio Saxones, made up of urban artisans and merchants supported by a large land-owning yeomanry. Saxons viewed themselves as part of Transylvania's elite,

\footnotetext{
The term Saxones was commonly applied in East Europe to all Germans, regardless of their place of origin. Harald Roth, 'Autostereotype als Identifikationmuster: zum Selbstbild der Siebenbürger Sachsen', in Das Bild des Anderen in Siebenbürgen, ed. by Konrad Gündisch, Wolfgang Höpken, and Michael Markel (Cologne, I998), p. I83.
} 
alongside the (predominantly Hungarian) nobility and distinct from the (predominantly Romanian) landless serfs. Thus, ethnicity, alongside membership of the Lutheran Church of Transylvania, reinforced the Saxons' estate-based particularist identity.

While Transylvania was not static before the mid-nineteenth century, from the I860s the Saxons underwent a series of changes of a scale and speed not previously experienced. These changes might be loosely grouped under the rubric of modernity, a process historian John Darwin sees as defined by a 'scale of achievement' and a move towards greater 'social efficiency'. ${ }^{2}$ Politically, the increasing centralization of the Habsburg Empire from the late eighteenth century resulted in the weakening and eventual stripping away of privileges of the natio Saxones, which was finally abolished in I876. Centralization triggered growing liberal nationalist movements, not least amongst the Saxons' Hungarian and Romanian neighbours. From the Ausgleich of 1867 , Saxons found themselves in nationalist Hungary under the Dual Monarchy. Following the First World War, Transylvania became part of equally nationalist Romania. Together, centralization, liberalism, and nationalism transformed Saxons from an elite stratum into what Cohen has described as a 'declining upper-strata minorit[y]'. ${ }^{3}$ This process was not distinctive to the Saxons; formerly privileged elites were transformed into national minorities across Central Europe by the nationalization of formerly dynastic empires before the First World War and the replacement of the continental empires with nation-states thereafter. ${ }^{4}$

Economic and social modernization compounded political changes. Economic integration through the railway brought new commercial opportunities, but also exposed Saxons to competition from more developed parts of the Dual Monarchy and Europe generally. Economic reform eroded traditional social practices, while improved transportation facilitated the adoption of mass consumer culture, undermining Saxon folk culture. Intellectually, new disciplines such as ethnography and eugenics, and new economic models such as cooperatives provided tools for interpreting and responding to change.

The transformative influences Saxons experienced were the product of transnational processes that altered societies across Europe. Saxons faced significant challenges in responding to their changing environment. They constituted a small, geographically dispersed minority, unable to form a state of their own. At the same time, Hungarian and Romanian elites either denied minorities a share of, or set assimilation as the price for access to, state resources. However, a rising sense of ethnic particularism led the community's educated middle class (locally known as the Literati) to see these challenges within a specifically Saxon framework. By imagining the transnational impacts of modernization in local and ethnically specific terms, the Literati attempted to reduce them to a scale a small minority might effectively respond to. Nonetheless, the scope of the challenges often made localized responses ineffective.

While far from the only sphere in which Saxons responded to the impacts of modernity, viniculture and wine provide a particularly insightful context in which to

\footnotetext{
John Darwin, After Tamberlane: The Rise and Fall of Global Empires, I400-2000 (London, 2007), pp. $25-27$. Gary B. Cohen, The Politics of Ethnic Survival: Germans in Prague, I86I-I9I4 (Princeton, I98I), p. 4.

4 Rogers Brubaker, Nationalism Reframed: Nationhood and the National Question in the New Europe (Cambridge, 1996), pp. 6-7.
} 
consider Saxon responses to modernity, by ethnographers, economists, moral conservatives, and the medical profession. Viniculture was a widespread practice amongst Saxons. Although occupying only 2.8 per cent of total Saxon-owned land in 1883 , vineyards could be found in 78.4 per cent of communities in which Saxons lived. ${ }^{5}$ The Weinland, the watershed of the Große Kokel and Kleine Kokel rivers (Târnava Mare and Mic/Nagy- and Kis-Küküllö $)^{6}$ that was Transylvania's pre-eminent wine growing district, was the area of densest Saxon habitation. ${ }^{7}$ Saxons were over-represented amongst vineyard owners, owning a third of all land under viticulture in Transylvania by the First World War. ${ }^{8}$ At the same time, viniculture was also a transnational industry par excellence, subject to a global market, international developments in manufacturing, the transnational spread of diseases such as phylloxera, and international changes in tastes. The consumption of wine similarly reflected global shifts in alcohol production and consumption, while abstinence campaigners looked to their international colleagues for inspiration. Nonetheless, the Literati consistently imagined a specifically Saxon wine industry and shaped their responses accordingly. Furthermore, the Literati imbued wine with many symbolic meanings beyond the economic importance of viniculture and the widespread consumption of wine. Wine was at once a repository of Saxon tradition, a context for social and economic modernization, and a dangerous social ill leading to acculturation, racial decline, and financial ruin.

Below, I examine three broadly defined approaches to wine and viniculture. Ethnographers found in viticulture evidence of the Saxons' high cultural standing, and of their 'civilizing' role in Transylvania, by which they sought to legitimize the Saxon presence there. They also used the 'German' origins of Saxon viniculture to reinforce ties to Germany. By comparison, agronomists identified in viniculture the potential to revitalize the Saxons' flagging financial circumstances. Their attempts to modernize Saxon viniculture conflicted with ethnographers' celebration of tradition. By contrast, the Saxon abstinence movement saw the production and consumption of alcohol as inimical to both the traditions and the financial wellbeing of the community. Eugenicist in outlook, anti-alcohol campaigners argued that wine threatened the community's ability to support a healthy population. In viniculture and wine, ethnographers, economists, and abstinence campaigners sought to take advantage of, or ameliorate, the transformations the community was undergoing. Ultimately, however, they were constrained by the community's minority status and the scale of the processes to which they were responding.

\section{The repository of tradition}

From the late eighteenth century, but especially from the I850s, the Literati embraced ethnic particularist understandings of Saxonness, appealing to the Saxons' antiquity,

5 Hans Acker, Weinland Siebenbürgens: Achthundert Jahre Weinbaukultur im Karpatenbogen (Wiesbaden, I993), p. 54.

6 I use German place names for all locations without commonly used English signifiers. I also provide Romanian and Hungarian alternatives on first mention.

7 Zsolt Bottlik, 'Ethnische Raumstruktur der sächsischen Bevölkerung im ehemaligen Komitat Großkokeln (I850-I992)', Zeitschrift für siebenbürgische Landeskunde, 5 (2000), 209-I7.

8 Carl Göllner, Die Siebenbürger Sachsen in den Jahren I848-I9I8 (Cologne, I988), p. 74. 
their 'high' cultural status as Germans, and their historic 'civilizing mission' in Eastern Europe to legitimize their place in Transylvania.9 Saxon ethnography [Volkskunde] reinforced a strongly local, particularist understanding of Saxonness that remained rooted in local folk practices, Lutheranism, and memories of the estate. Saxon ethnographers reinforced ethnic conceptions of Saxonness by recording Saxon folk customs and reinforcing the notion of a shared and distinctive Saxon culture. At the same time, they traced Saxon traditions back to their 'German' origins, and claiming a privileged role for Saxons in introducing 'high' culture into the region. ${ }^{\text {IO }}$ In part, this interest reflected the rise of ethnography as a discipline throughout Europe, ${ }^{\text {II }}$ in which Saxons played an active if peripheral role. ${ }^{\mathrm{I} 2}$ However, like their counterparts in other communities, Saxon ethnographers understood their discipline in a nationalist context, supporting Saxon claims to the status of a distinct national community entitled to determine its own destiny.

Saxon ethnographers identified in viniculture evidence of the Saxons' high cultural standing, their German origins and their historical contributions to the region. From the eighteenth century, West Europeans essentialized Eastern Europe as a primitive and backwards Other in contrast to themselves. ${ }^{13}$ East Europeans increasingly internalized these values, although they often found grounds for asserting the exceptionalism and 'Westernness' of their own community. ${ }^{14}$ To the Literati, it was the Saxons' German origins that marked them as a Western Kulturvolk, and thus superior to their Eastern, Naturvolk neighbours. ${ }^{15}$ For example, in I858 Johann Fabini (I825-99), a gymnasium teacher in Mediasch (Mediaş/Medgyes), the principal town of the Weinland, traced the introduction of viticulture to Transylvania by German settlers in I206. Furthermore, Fabini found botanical evidence for his claims: he identified two grape varieties in Transylvania that he believed had been introduced by the first settlers from their former homeland [Urheimat] around the Rhine and Mosel Rivers, Rässer (developed from Gouais blanc), and Gornisch (derived from Elbling). ${ }^{16}$ For Fabini, wine not only demonstrated the Saxons' German origins, but their role in civilizing the region through the introduction of agriculture.

9 Andreas Möckel, 'Geschichtsschreibung und Geschichtsbewusstsein bei den Siebenbürger Sachsen', in Studien zur Geschichtsschreibung im I9. Und 20. Jahrhundert, ed. by Paul Philippi (Cologne, 1967), pp. 4-5; Paul Philippi, 'Zum Selbstverständnis der Siebenbürger Sachsen im Zeitalter des Nationalismus und danach', in Zur Interethnik: Donauschwaben, Siebenbürger Sachsen und ihre Nachbarn, ed. by Ingeborg Weber-Kellermann (Frankfurt, 1978), pp. 236-37; Roth, 'Autostereotype als Identifikationmuster', pp. I88-90.

ro Sacha E. Davis, “'Our Faithfully Kept, Age-old Inheritance”: Transylvanian Saxon Folk Customs, Particularism and German Nationalism between the Wars', in Europe's Expansions and Contractions, ed. by Evan Smith (Adelaide, 2009), pp. I99-220.

II Hans Vermeulen, 'Origins and Institutionalization of Ethnography and Ethnology in Europe and the USA, I77I-I845', in Fieldwork and Footnotes: Studies in the History of European Anthropology, ed. by Hans F. Vermeulen and Arturo Alvarez Roldán (London, 1995), pp. 39-59.

I2 Charles Boner, Transylvania: Its Products and its People (London, I865), pp. 225-26.

${ }^{3}$ Larry Wolff, Inventing Eastern Europe: The Map of Civilization on the Mind of the Enlightenment (Stanford, I994).

${ }^{\text {I4 }}$ Maria Todorova, Imagining the Balkans (Oxford, I997), pp. 38-6I.

I5 Sacha E. Davis, 'East-West Discourses in Transylvania: Transitional Erdély, German-Western Siebenbürgen or Latin-Western Ardeal?', in The East-West Discourse: Symbolic Geography and its Consequences, ed. by Alexander Maxwell (Oxford, 20II), pp. I36-46.

I6 Hans Acker, 'Die siebenbürgische Obst- und Weinbau zwischen den beiden Weltkriegen I919/1939', in Siebenbürgen zwischen den beiden Weltkriegen, ed. by Walter König (Cologne, 1994), pp. 89-91; Acker, Weinland Siebenbürgens, p. 48 . 
Similarly, Lutheran pastor and folklorist Adolf Schullerus (I864-I928), writing in I926, traced a third grape variety to the Urheimat: 'Perhaps the assumption is not too bold, that the "Medeweimer" grape that has become indigenous [to Transylvania] is the Riesling vine once brought from the original homeland'. ${ }^{17}$ Schullerus also traced viticulture techniques in Transylvania back to the Mosel region. At the same time, he underlined the specifically Saxon character of these viticulture practices. For example, he identified Gallo-Roman loanwords in the Saxon viti- and viniculture vocabulary, demonstrating both the Saxons' origins in the Urheimat and the distinct character of the Saxon dialect, Sächsisch. ${ }^{18}$ Thus, for Schullerus, Saxon viniculture demonstrated the Saxon civilizing role and the German origins of Saxon culture, but also its specifically Saxon nature.

Folklorists emphasized the ubiquity and traditional character of Saxon viniculture as well as viticulture. However, wine played a smaller role in Saxon drinking culture than Schullerus's emphasis implied. As he acknowledged, Saxons also traditionally produced and consumed other beverages, including beer, and brandies made from apples, pears, berries, and especially plums. ${ }^{19}$ In addition, they increasingly drank industrially produced spirits. According to one estimate, in the I920s Saxons consumed approximately 7 litres of wine, versus I $_{5}$ litres of beer and 12 litres of spirits per capita per annum. ${ }^{20}$ These figures reflected broader changes in European drinking habits. In the early nineteenth century, technological improvements allowed for mass brewing and distillation, leading to rapidly declining alcohol prices per volume. ${ }^{2 \mathrm{I}}$ Grain producers in Transylvania, as well as in neighbouring Poland and Romania, embraced industrial alcohol production from the mid-nineteenth century as a means of disposing of surplus grain. Increased availability and declining prices fuelled an increase in consumption. ${ }^{22}$ Schullerus's emphasis on wine reflected its symbolic value, rather than actual consumption levels.

Ethnographers might also have drawn upon beer brewing and schnapps distilling to demonstrate their German connections. Alcohol producers sent their sons to Germany to learn the latest techniques and bring back modern technology. ${ }^{23}$ However, nationalist ethnographers were primarily interested in capturing disappearing traditions, rather than contemporary practices. ${ }^{24}$ Commercial breweries and distilleries increasingly displaced traditional manufacturing techniques, making spirits and

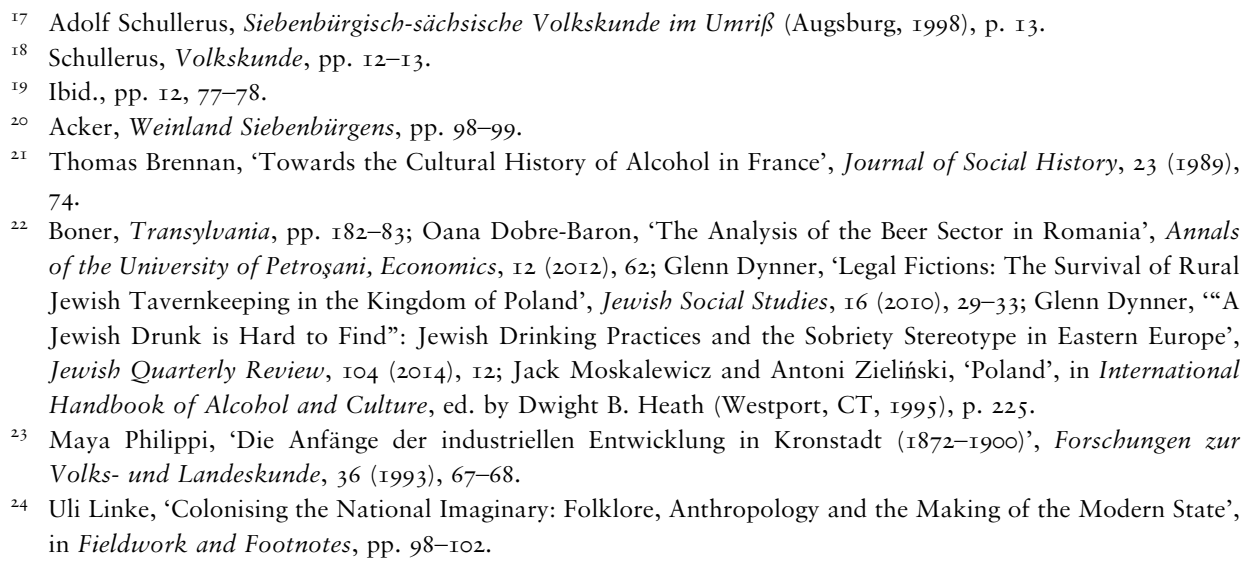
of the University of Petroşani, Economics, I2 (2012), 62; Glenn Dynner, 'Legal Fictions: The Survival of Rural Jewish Tavernkeeping in the Kingdom of Poland', Jewish Social Studies, I6 (2010), 29-33; Glenn Dynner, “"A Jewish Drunk is Hard to Find”: Jewish Drinking Practices and the Sobriety Stereotype in Eastern Europe', Jewish Quarterly Review, I04 (2014), I2; Jack Moskalewicz and Antoni Zieliński, 'Poland', in International Handbook of Alcohol and Culture, ed. by Dwight B. Heath (Westport, CT, I995), p. 225.

23 Maya Philippi, 'Die Anfänge der industriellen Entwicklung in Kronstadt (I872-1900)', Forschungen zur Volks- und Landeskunde, 36 (1993), 67-68.

24 Uli Linke, 'Colonising the National Imaginary: Folklore, Anthropology and the Making of the Modern State', in Fieldwork and Footnotes, pp. 98-102. 
beer less attractive subjects for ethnographic study. ${ }^{25}$ Ethnographers saw distilleries and breweries primarily as destroying Saxon traditions, rather than reinforcing connections to the Urheimat. Other European wine growing areas in Europe also resisted mass distilled alcohol as 'foreign'. ${ }^{26}$ Furthermore, large-scale manufacturing fitted poorly with the Saxon self-image, rooted in the stereotypes of the estate. Schullerus's somewhat idealized depictions of Transylvania reveal a landscape of small towns and villages inhabited by Saxon peasants, artisans, and pastors, not of factories, industrialists, and the proletariat. ${ }^{27}$

Viniculture also played a significant role in Saxon claims to territory, over which they had less control following the dissolution of the estate. The natio Saxones had governed an extensive territory in Southern Transylvania, of which the Weinland formed the core. Saxons lost administrative control of the Weinland with the dissolution of the estate. For Saxons, grapes and their produce were an essential part of the Transylvanian landscape, and that landscape was specifically Saxon. In I846 the German author Maximilian Leopold Moltke (I8I9-94) penned the poem Siebenbürgen, Land des Segens, the first stanza of which describes the region as follows:

Siebenbürgen, Land des Segens,

Land der Fülle und der Kraft,

Mit dem Gürtel der Karpaten

um das grüne Kleid der Saaten.

Land voll Gold und Rebensaft!
[Transylvania, land of blessings,

Land of abundance and strength,

With the girdle of the Carpathians around the green dress of crops.

Land full of gold and grape juice! $]^{28}$

While Moltke wrote his poem for all Transylvanians, it was most popular with Saxons, who adopted it as a national anthem. ${ }^{29}$

By treating viniculture as specifically Saxon, despite the many non-Saxons in the region engaged in the trade, Saxons laid claim to territory. Saxon authors tended to view the Weinland as a specifically Saxon region, despite forming less than half the population there. For example, the essayist Otto Folberth portrayed the Weinland and his birthplace Mediasch as a monocultural landscape. The many Romanians, Hungarians, Roma, Jews, and other inhabitants of the region were entirely lacking from his descriptions. ${ }^{30}$ Folberth belonged to the 'Klingsor Circle' of writers who, in the I920s, attempted to reinforce Saxon claims to Transylvania through landscape descriptions. ${ }^{3 \mathrm{I}}$ The identification of viticulture in Transylvania as a specifically Saxon concern continues to shape contemporary scholarship. ${ }^{32}$

25 History of Transylvania, ed. by Zoltán Szász, vol. 3: From I830 to I9I9 (New York, 2002), pp. 53I-32 <http:// mek.oszk.hu/03400/03407/html/342.html> [accessed I5 October 20I4]; Philippi, 'Die Anfänge', pp. 77-78.

26 Brennan, 'Alcohol in France', p. 8I.

27 Schullerus, Volkskunde, pp. I-2I.

28 Acker, Weinland Siebenbürgens, p. I09.

29 Karl-Heinz Brenndörfer, 'Siebenbürgenlied ins Rumänische übertragen', Siebenbürgische Zeitung, I5 May 2002, <http://www.siebenbuerger.de/zeitung/artikel/alteartikel/IO28-siebenbuergenlied-ins-rumaenische.html> [accessed I5 October 20I4].

30 Otto Folberth, 'Der Mediascher', Klingsor, 5 (I928), I5I-53; Otto Folberth, 'Die Mediascher Landschaft', Klingsor, 5 (I928), 202-07. According to the I9Io census, Saxons made up $4 \mathrm{I} \%$ of the population of the county of Große Kokel, and $\mathrm{I} 8.3 \%$ of the population of the county of Kleine Kokel. A Történelmi Magyarország atlasza és Adattára 19I4, ed. by László Zentai (Pécs, 200I), pp. 72-73.

${ }^{3}$ Davis, 'East-West Discourses', p. I36.

32 E.g. Acker, Weinland Siebenbürgens. 
Ironically, Saxon ethnographers and writers were following transnational patterns in associating specific varietals and wine growing regions with nationalism. For example, in Western Europe, champagne and the Champagne district played a similar role in France from the nineteenth century. ${ }^{33}$ In Eastern Europe, Hungarian nationalists extolled the virtues of tokaj as a specifically Hungarian wine. Pride in tokaj played an important role in Hungarian claims to the Tokaj region as a specifically 'Hungarian' landscape (as did 'bull's blood' wine for the Eger region). ${ }^{34}$ Interestingly, Schullerus listed tokaj (locally known as Schmijer) amongst the varietals grown by Saxons. However, he placed little emphasis on tokaj or other varieties post-dating Saxon migration to Transylvania; they did little to demonstrate the Saxons' antiquity or German origins. Furthermore, tokaj had already been claimed as a 'Hungarian' national wine. For Schullerus, the symbolic significance of varietals outweighed the degree to which they were cultivated. ${ }^{35}$

Greater ethnic diversity in Eastern Europe gave national claims to wine-growing regions a different significance to those in Western Europe. Despite some migrant workers in Champagne, the French state's claim to the region was not in dispute. Champagne stood primarily as a symbol of French sophistication and 'authentic' connection to terroir, rather than as a territorial claim. ${ }^{36}$ By comparison, by asserting the 'Hungarian' character of Tokaj, Hungarian nationalists staked their claim to a region in which a significant minority of inhabitants were Slovakians; indeed, the region was divided between Hungary and Slovakia after the First World War. Saxon claims to the Weinland were even more fragile than Hungarian claims to Tokaj, given their smaller numbers and lack of a state to enforce their control.

Saxon interpretations of Transylvania's wine history directly contradicted Romanian interpretations. Romanian nationalists traced their origins to the ancient Dacians and the Romans who had conquered them. ${ }^{37}$ Romanian viniculture scholar C. Theodorescu linked wine to this ethnogenesis, arguing that Dacians had practiced viniculture in Romania as early as 3000 BCE, and that Roman influences had improved the practice. Far from demonstrating a German influence, Theodorescu contextualized the Târnava wine-growing district (that is, the Weinland) within the framework of Daco-Roman viniculture. ${ }^{38}$ Thus, Saxon claims to the Weinland competed with, and were ultimately unable to influence, Romanian claims to the landscape. ${ }^{39}$

The Literati, then, turned to viniculture in order to attest to the Saxons' claims to 'high' cultural status and to legitimize Saxon claims to territory in Transylvania. The modern discipline of ethnography provided the Literati with the tools to assign new,

33 Kolleen M. Guy, When Champagne Became French: Wine and the Making of a National Identity (Baltimore, 2003).

34 George W. White, Nationalism and Territory: Constructing Group Identity in Southeastern Europe (Lanham, 2000), p. 90.

35 Schullerus, Volkskunde, p. I3.

36 Guy, Champagne, pp. 2-5, 2I-24.

37 Virgil Cândea, 'The "Dark Millenary" in the History of the Romanians as Seen by Constantin G. Giurescu', in Romania between East and West: Historical Essays in Memory of Constantin G. Giurescu, ed. by Stephen Fischer-Galati, Radu R. Florescu, and George R. Ursul (Boulder, I982), pp. II 5-26.

38 C. Theodorescu, 'The Romanian Vineyards and Wines', in Savoury Rumanian Dishes and Choice Wines (Bucharest, I939), pp. I35-37, I50-5I.

39 Davis, 'East-West Discourses'. 
politically useful meanings to the traditions of the past, in order to respond to the Saxons' minority status within national states. ${ }^{40} \mathrm{~A}$ popular and highly respected writer, Schullerus's works were widely read. The Lutheran Church, in which Schullerus held the second most senior post, used his work widely in education programmes from primary school [Volksschule] through to adult education and teachers' seminaries. Ethnographers played a key role in propagating and reinforcing Saxon particularism within widening circles of the Saxon community. However, Hungary and Romania were exclusivist national states, and unwilling to share state resources. ${ }^{4 \mathrm{I}}$ Hungarian and Romanian nationalists were unmoved by Saxon appeals to higher cultural standing; ethnographic descriptions of Saxon viniculture were unable to ameliorate the Saxons' minority status within Hungary or Romania.

\section{Social and economic modernization}

While folklorists looked to viniculture for the traditions it embodied, Saxon economists viewed wine as an industry with a vibrant future. Through specialist vintners' cooperatives, they hoped to transform viniculture into a modern export industry capable of securing the Saxons' economic future and providing the basis for a more egalitarian society. Economics assumed a particular urgency as, unable to access the resources of the exclusivist national state, Saxons depended on community funding in order to support the Church, its schools, and other cultural and social associations. ${ }^{42}$ Furthermore, Saxons faced substantial economic challenges from the midnineteenth century. The spread of the railway to Transylvania from the 1850 o opened the region to competition from more industrialized parts of the Habsburg Empire and integrated Transylvania more firmly to the global economy. ${ }^{43}$ The abolition of Saxondominated guilds in 1872 , as well as the estate, limited Saxons' ability to protect their manufacturing sector through restrictive economic practices. ${ }^{44}$ Depressed global agricultural markets impacted severely on Saxon farmers, leading them to join the mass migration from Eastern Europe to the United States, a process facilitated by the railways. ${ }^{45}$ The Saxon economic position worsened after the First World War, when the combination of lost investments in war loans to the Central Powers and an unfavourable exchange rate to the Romanian Leu dramatically reduced Saxon capital. Furthermore, Saxons lost approximately half their agricultural land in the I92 I Agrarian reforms. ${ }^{46}$ Temporarily halted by the War, migration recommenced. By 1923

40 Philippi, 'Selbstverständnis', pp. 236-37; Eric Hobsbawm, 'Introduction: Inventing Traditions', in The Invention of Tradition, ed. by Eric Hobsbawm and Terrence Ranger (Cambridge, I983), pp. I-I4.

4I Katherine Verdery, 'Introduction', in National Character and National Ideology in Interwar Eastern Europe, ed. by Ivo Banac and Katherine Verdery (New Haven, I995), pp. xiii-xxvi.

42 Karl Wolff, 'Der Siebenbürger Sachsentag in Hermannstadt am I7. Juni I890', in Wolff, Schriften und Reden, ed. by Michael Kroner (Bukarest, I976), p. I44.

43 Gerhard Rosegger and John H. Jensen, 'Transylvanian Railways and Access to the Lower Danube, I856I9I4', East European Quarterly, 29 (I995), 427-48.

44 Philippi, 'Die Anfänge', pp. 67-68.

45 Oskar Wittstock, Unsere Volksgenossen in Amerika (Hermannstadt, I910), pp. 3-4.

${ }^{6}$ Harald Roth, Politische Strukturen und Strömungen bei den Siebenbürger Sachsen I9I9-I933 (Köln, I994), pp. $84-89$. 
more than Io per cent of Saxons lived in America. ${ }^{47}$ As a small minority, population 'loss' due to unchecked mass migration appeared to present a threat to the very survival of the Saxon community. ${ }^{4}$

The banker Carl (Karl) Wolff (I849-I929), from I890-I918 chair of the peak Saxon political organization, the German-Saxon People's Party (Deutsch-Sächsische Volkspartei), was particularly concerned about the state of agriculture, which was the primary source of employment for three-quarters of the Saxon population. Wolff advocated the creation of savings and loans cooperatives to increase agricultural income by purchasing or redeeming farmland and modernizing Saxon agriculture. The immediate impetus for the development of cooperatives came from similar efforts in Hungary. However, Wolff framed his cooperatives as specifically Western; his stated models for emulation were from Denmark, Switzerland, Britain, and especially the German cooperatives founder Friedrich Wilhelm Raiffeisen (I8I8-88). ${ }^{49}$ To Wolff, the successful West European cooperatives in themselves represented the modernity he wished to emulate, in a way that the nascent Hungarian cooperatives did not; the Saxon 'civilizing myth' reinforced the Saxon tendency to look westwards for inspiration, rather than to their neighbours. Wolff may also have adopted Raiffeisen's model to differentiate Saxons from Hungarians who, after some debate, rejected Raiffeisen's approach. ${ }^{\circ}$ In ethnically divided East Europe, cooperatives took on a distinct significance as national bodies, representing specific national interests. Transylvanian Saxons, Hungarians, and Romanians established separate cooperatives. ${ }^{\text {I }}$ Thus, Wolff founded village consumer cooperatives in 1905 to discourage Saxons from joining ethnic-Hungarian consumer cooperatives that had recently expanded into Saxon-inhabited communities..$^{2}$

Wolff viewed cooperatives as specifically Saxon institutions that continued the collectivism of the estate and guilds. Influenced by stereotypes of Saxons as artisans and yeomen, he sought to maintain a society of traditional smallholders, albeit through the adoption of modern production methods. Nonetheless, Wolff, like other nineteenth-century cooperative founders, was also a social engineer attempting to produce a more egalitarian alternative to large-scale capitalism..$^{53}$

In addition to savings and loans cooperatives, Wolff advocated specialist cooperatives to develop sectors with potential for value-adding and creating export markets.

47 Bertold Buchalla, 'Die Diaspora der evangelischen Landeskirche A.B. in Siebenbürgen und in Nordamerika', in Die evang. Landeskirche A.B. in Siebenbürgen (Jena, I923), p. 52; and Michael Kroner, Siebenbürger Sachsen außerhalb Siebenbürgens (Nürnberg, 200I), p. 24.

$4^{8}$ Oskar Wittstock, Strandgut von einer Amerikareise (Hermannstadt, I910), p. 37.

49 Carl Wolff, 'Sind ländliche Vorschussvereine notwendig?' in Wolff, Schriften und Reden, pp. I76-77.

5o Osamu Ieda, 'The Rural Cooperatives and members' Liability from a Historical Perspective: The Hungarian Case', in The New Structure of the Rural Economy of Post-Communist Countries, ed. by Osamu Ieda (Hokaido, 200I), pp. 4-6, <http://src-h.slav.hokudai.ac.jp/kaken/ieda200I/ieda-contents.html> [accessed 20 February 2013].

${ }^{51} \quad$ Ernst M. Wallner, 'Strukturen und Funktionen des Siebenbürgisch-sächsischen Vereins-, Genossenschafts- und Verbandswesens', Forschungen zur Volks- und Landeskunde, 36 (I993), 27.

52 Ernst Wagner, 'Carl Wolff — Wirtschaftsfachmann und Politiker (I849-1929)', Siebenbürgische Zeitung, I5 May I98I, p. 9.

53 Michael Kroner, 'Vorwort', in Wolff, Schriften und Reden, p. 26. 
Wolff identified just such potential in viniculture. ${ }^{54}$ Throughout Europe, improvements in wine production, storage, and transport allowed for a new mass export market in wine from the early nineteenth century. ${ }^{55}$ While poor transport prevented Saxons from participating in this market until the $1860 \mathrm{~s},{ }^{56}$ the railway offered new opportunities for Saxon producers.

However, viniculture needed considerable reform in order to be competitive. Improvements in wine manufacturing and distribution techniques in West Europe in the late eighteenth and early nineteenth centuries had not been implemented in Transylvania, primarily due to the lack of export opportunities. ${ }^{57}$ Furthermore, techniques for tending vines, fertilization and pest control, which had not changed since medieval times, improved rapidly in Western Europe in the second half of the nineteenth century. ${ }^{8}$ Saxons had to keep up with reforms in order to remain competitive. These inefficiencies gained in significance as the railway brought Transylvanian producers into direct competition with wine regions in Hungary. ${ }^{59}$

Furthermore, to Wolff, viniculture was in particular need of protection. Most Saxon farmers sold their produce to commercial vintners in the form of unfermented or slightly alcoholic must (grape juice). ${ }^{60}$ Merchants took advantage of farmers' cash shortfalls between harvests, offering advances against the grape crop and thus controlling prices. Alcohol consumption also put peasants at risk. Wine merchants were often local tavern owners who produced their own alcohol for sale. Wolff echoed popular accusations that innkeepers sold alcohol on credit beyond the means of the peasantry to repay, using the debt to seize the peasants' land, or as leverage for advantageous contracts over the next year's harvests. ${ }^{6 \mathrm{I}}$ Wolff's cellar cooperatives aimed to enable farmers to exercise greater control over prices. ${ }^{62}$ Consumer cooperatives also established cooperative taverns to meet local demand for alcohol. ${ }^{63}$

Wolff's understanding of the relationship between farmer and merchant reflected the strong salience of ethnic identity in Transylvania. Many tavern owners in Transylvania were Jews of Galician origin, ${ }^{64}$ where hostelry had been one of the few professions open to them. ${ }^{65}$ Increasing restrictions on Jewish tavern-keeping in Russian Poland in the nineteenth century may also have encouraged migration to Transylvania. ${ }^{66}$ From the mid-nineteenth century, popular stereotypes associated

\footnotetext{
54 Wolff, 'Vorschussvereine', p. I8I; and Karl Wolff, Das Genossenschaftswesen in Land und Stadt (Hermannstadt, I9I0), pp. 30-3I.

55 Brennan, 'Alcohol in France', pp. 73-74.

56 Boner, Transylvania, pp. I66-68.

7 Acker, Weinland Siebenbürgens, p. 25; Boner, Transylvania, pp. I66-68.

8 Brennan, 'Alcohol in France', pp. 3-74; Acker, Weinland Siebenbürgens, p. 25.

Zweiter Jahresbericht über die ländlichen Spar-und Vorschuß-Vereine (Hermannstadt, I888), pp. II-I2.

so Acker, 'Weinbau', p. I07.

6r Oana Mihaela Tămaş, 'Alcoholism and Ethnic Stereotypes in Modern Age Transylvania', Romanian Journal of Population Studies, 3.2 (2009), II5-I7.

62 Wolff, 'Vorschussvereine', pp. I77-88.

63 'Bericht über den Stand der Fürsorge im Jahre I925', EV 4-I927/Kirchliche Blätter, 28 April I927, p. I.

${ }^{6}$ Nadia Badrus, 'Das Bild der Siebenbürger Sachsen über die Juden. Einige Anhaltspunkte', in Das Bild des Anderen, pp. 85-97.

${ }_{65}$ Moskalewicz and Zieliński, 'Poland', p. 225.

${ }^{66}$ Dynner, 'Legal Fictions'.
} 
Jews with the role of unscrupulous innkeeper. ${ }^{67}$ For Wolff, who had strong völkisch leanings, ${ }^{68}$ this was a struggle between the Saxon peasant and the 'Jewish publican' [jüdischer Schankwirt]. ${ }^{6}$ Saxon racialist thinking was strongly influenced from Germany, as is discussed below. However, the stereotype of the Jewish innkeeper was a specifically Eastern European idea, well entrenched in Poland and Galicia. It was apparently absent from negative stereotypes of rural Jews in Germany and German-speaking Austria, where the production, distribution and sale of alcohol were 'socially integrated' (that is, dominated by non-Jewish Germans). Of course, non-Jewish tavern keepers also sold alcohol on credit. ${ }^{70}$ However, for Wolff, Jewishness became the principle means of discrediting economic practices of which he disapproved. ${ }^{7 \mathrm{I}}$

Wolff's stereotypes reflected his anti-Semitism more than any ethnic stratification on economic lines. The consolidation of alcohol production in the second half of the nineteenth century increasingly took viniculture out of the hands of tavern owners. Many large-scale Transylvanian wine manufacturers were Saxon. Amongst the largest alcohol producers were the Saxon brewers Friedrich Czell and Sons (founded I854) in Neustadt (Cristian/Keresztényfalva), who produced wine, grain spirits, and beer. ${ }^{72}$ Wolff did not oppose large-scale industry; as a banker, he encouraged investment from Germany in large-scale Saxon concerns. However, he did not list large-scale distilleries and breweries amongst the industries he considered worth expansion. ${ }^{73}$ Large-scale industry in this sector did not match Wolff's vision of a community of smallholders. Rather, cooperative officials aimed to found sufficient numbers of cellar cooperatives to achieve the necessary scale to bypass the big manufacturers, and create a central cellar to handle sales. ${ }^{74}$

Wolff's aim, then, was to create vintners' cooperatives that would also reinforce traditional Saxon social structures, separate Saxons from Hungarian and Romanian growers, and make Saxon viniculture competitive in the international wine market. The first cellar association was founded in Arbegen (Agârbiciu/Szászegerbegy) around I886. A handful of others followed in the next few years. According to the secretary of the League of Raiffeisen Cooperatives, Gustav Adolf Schuller, cellar cooperatives were to modernize production through a number of means, including improving

67 Boner, Transylvania, pp. 6I7-I8; Tămaş, 'Alcoholism', pp. II6-I7.

68 Hildrun Glass, Zerbrochene Nachbarschaft: Das deutsch-jüdische Verhältnis in Rumänien, 1918-1938 (München, I996), pp. 295-97.

69 Wolf, 'Vorschussvereine', p. 178.

70 Helmut Walser Smith, 'The Discourse of Usury: Relations between Christians and Jews in the German Countryside, I880-I9I4', Central European History, 32 (I999), 255-76; Dynner, 'Legal Fictions', pp. 3I-32; Irmgard Eisenbach-Stangl, 'The Beginnings of Galician and Austrian Alcohol Policy: A Common Discourse on Dependence', Contemporary Drug Problems, 20 (I993), 706-I7.

${ }_{71}$ Karl Wolff, Das deutsche Volk in Europa: Erinnerungen und Gedanken über den Wiederaufbau (Hermannstadt, I924).

72 History of Transylvania, p. 6I7; Philippi, 'Die Anfänge', pp. 75-76; Acker, 'Weinbau', p. I07.

73 Carl Wolff (ed.), Bemühungen um das siebenbürgisch-sächsische Gewerbe (Hermannstadt, I90I), pp. 1-3I.

74 Zweiter Jahresbericht, pp. II-I2; G. A. Schuller, 'Die Raiffeisenorganisation im siebenburg. Sachsenlande in ihrer Entwicklung von I885-1910', in Carl Wolff als Direktor der Hermannstädter Allgemeinen Sparkassa I885 bis I910: Festschrift aus Anlaß der 25. Jahreswende seiner Erwählung, ed. by Direktionsrat der Hermannstädter Allgemeinen Sparkassa (Hermannstadt, I9Io), p. I77. 
cellaring and encouraging better vine dressing. ${ }^{75}$ In order to be competitive, Saxon viniculture also had to adapt to changing wine fashions. One of the main methods by which production might be improved and market tastes met was through modernization of vine stock. For example, in I888 the chair of the Arbegen cellar cooperative, Pastor Viktor Rideli, urged the replacing of existing vine stock with varieties that offered higher yields, such as Riesling, Traminer, and Burgundy. Furthermore, must from these varieties was also more desirable, fetching two to three times the market price. $^{76}$

In urging the modernization of vine stock, cooperative officials conflicted with the aims of ethnographers. As in France, the Saxon wine industry used the 'traditional' character of Saxon wine growing as a marketing technique, ${ }^{77}$ for example to dismiss criticisms from abstinence campaigners. ${ }^{78}$ However, Rideli advocated the abandonment of the traditional varieties valued by folklorists like Schullerus and Fabini as evidence of Saxon antiquity and Germanness, in order to cater to international tastes.

As well as international markets, Saxon producers were subject to the transnational spread of vine pests. The American louse phylloxera vastatrix arrived in West Europe in 1863 , ravaging French vineyards, and driving up international wine prices to the benefit of Central European producers not yet affected by the pest. ${ }^{79}$ However, the benefits were short-lived. Phylloxera reached Transylvania by 1889 , with devastating effect. Production fell to one-third of 1870 s levels by the early I $8905,{ }^{80}$ and rural migration to America rose sharply. ${ }^{8 \mathrm{I}}$ However, the phylloxera outbreak also assisted efforts to modernize Saxon vines, which had to be replaced with vines grafted on phylloxera-resistant rootstock.

Although phylloxera was a transnational phenomenon and the Hungarian government organized a state-wide response, Saxon agronomists preferred to treat the problem on local and specifically ethnic lines. Eschewing state-sponsored efforts to replace stock, local cooperatives distributed their own stock in concert with the Transylvanian Saxon Agronomics Association [Siebenbürgisch-Sächsischer Landwirtschaftsverein] (founded I845). ${ }^{82}$ In doing so, Saxon cooperatives maintained agency on ethnic lines, an aim in keeping with the ethnic segregation of Transylvanian economic associations and Saxon experiences of Habsburg Hungary as an exclusionary nation-state, baring Saxon access to state resources.

As elsewhere in Europe (for example, in France), the phylloxera outbreak also led to the modernization of pest control techniques, greatly improving crop reliability. ${ }^{83}$ Even so, Saxon producers remained at the mercy of wine markets. Difficult market

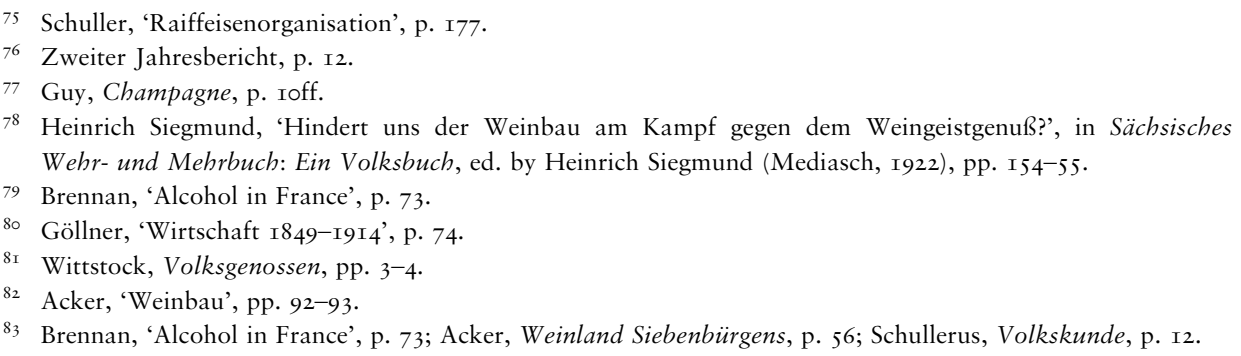


conditions and the impact of phylloxera repeatedly stymied efforts to expand specialist viniculture cooperatives before the First World War. All but one of the cooperatives had failed by I910. ${ }^{84}$

The need to intensify Saxon agricultural production, including through improving viniculture, gained greater urgency after the First World War and loss of land in the I92 I Agrarian Reforms. Romanian rule cut Saxon vintners from their traditional markets and put them in competition with producers in Wallachia, Moldavia, and Bessarabia. ${ }^{85}$ Massive overproduction suppressed the domestic wine market. The Transylvanian Saxon Agronomics Association continued to encourage farmers to modernize grape varieties, recommending in particular Welschriesling (first introduced in 1900) and Neuburger (first introduced in 1920). They also discouraged the planting of the two oldest varieties, Rässer and Gornisch, which Fabini believed had been introduced from the Urheimat. ${ }^{86}$ The Agronomics Association continued to recommend Mädchentraube (Schullerus's Medeweimer), but for its profitability, not its antiquity. The willingness of Saxon farmers to adopt new varietals suggests that while they may have taken pride in the 'German' origins of Saxon wine, tradition took second place to commercial viability, and the symbolic value of key varietals was not dependent on their continued widespread cultivation. Even Schullerus grudgingly accepted that agriculture had to modernize at the expense of tradition. ${ }^{87}$

At the same time, agronomists' aspirations to fully modernize viticulture were unrealistic. Traditional methods of soil preparation, fertilization, and vine dressing survived, primarily due to a lack of capital and the unsuitability of Transylvania's steep vineyards for mechanization. ${ }^{88}$ Saxon viniculture was subject to forces beyond the scope of Saxon producers to control, particularly the vagaries of the market. Although vintners updated their vine stock, profitability did not follow. Most Saxon viticulturists were small-scale mixed famers with $0.5^{-2}$ hectares of vineyards, and who could tend their crops themselves. The income from viticulture covered costs and made a small profit, but did not provide capital for future production improvements. Viticulture continued only because farmers and their families could provide most necessary labour; a contemporary study determined that, had labour been reimbursed at market rates, in 1927/28 Transylvanian vineyards would have lost on average I 4,395 Lei per hectare. These limits to viticulture's profitability occurred against a general agricultural crisis; most farmers went increasingly into debt in the I920s. ${ }^{89}$ While Saxon rural migration to America largely ceased in I924, this was due to new quotas the United States placed on East European migrants, rather than to any improvement in agriculture..$^{90}$

Difficult market conditions continued to stymie specialist cellaring cooperatives. After the First World War, Saxons were eligible to join the General Union of

${ }_{4}$ Schuller, 'Raiffeisenorganisation', pp. I78, 208-09; Acker, Weinland Siebenbürgens, pp. 95-96.

85 Acker, Weinland Siebenbürgens, p. 72.

86 Acker, 'Weinbau', pp. 96-97.

87 Schullerus, Volkskunde, p. 2.

88 Acker, 'Weinbau', pp. 95-96.

89 Ibid., p. 98; and Acker, Weinland Siebenbürgens, pp. 76-79.

90 Mae M. Ngai, Impossible Subjects: Illegal Aliens and the Making of Modern America (Princeton, 2003), p. 29. 
Viticulture Syndicates [Unirea Generala a Sindicatelor Viticole], founded in I9I9. However, the Romanian character of this organization was entirely at odds with Saxon ethnic particularism, so few Saxons joined. Rather, Saxon agronomists founded the Kokel Valley Vintner's Syndicate [Kokeltaler Weinbausyndikat] in I930/3I, as a specifically Saxon alternative to the General Union. However, the Syndicate primarily served as a supplier of cheap pesticides, not as a means of transforming the industry. $^{9 \mathrm{I}}$

Attempts to modernize viniculture underlie the opportunities and limits of possibilities for Saxons to institute economic reform. In viniculture, Wolff and other cooperative leaders imagined a vibrant modern industry that would provide a secure financial base for a 'traditional' society of Saxon smallholders. The ethnically segregated cooperatives Wolff advocated proved popular; by I9I0 there were more than two hundred cooperatives, located in all but the smallest Saxon villages..$^{92}$ The failure of specialist cellaring cooperatives stands out starkly against this background. Agronomists were able to update vine stock and improve agricultural practices, but could not influence wine prices. Rather than a source of economic relief, the continuing severity of conditions in the sector provided a key plank in abstinence campaigners' criticisms of viniculture, as discussed below.

\section{A dangerous social ill}

While folklorists and economists found positive elements in viniculture, the abstinence movement implacably opposed the manufacture and consumption of wine. Several broad groups among the Saxons came together to oppose wine production and consumption: the Good Templars, an abstinence society that supported conservative moral values, the Welfare Office of the Lutheran Church, and Saxon eugenicists. Eugenics provided a compelling methodology for modernizers and wouldbe state builders to delineate, control, and 'improve' national populations. ${ }^{93}$ Saxon eugenicists were no exception, seeking to strengthen the Saxons biologically, in part in compensation for their lack of statehood. ${ }^{94}$ Abstinence provided one avenue through which to achieve their aims.

Saxon abstinence campaigners advanced three intertwined arguments against alcohol production and consumption: that alcohol was morally corrosive; that it was physically harmful; and that it was economically harmful. Moral objections formed the key plank of the principal Saxon organization campaigning against alcohol consumption, the International Order of Good Templars, an abstinence society that was founded in America on Masonic lines in $185^{\circ}$, and that spread to the Germanspeaking world in the I870s and to Transylvania in I904. The Good Templars opposed alcohol consumption and a range of activities they associated with alcohol: smoking, gambling, foul language, materialism, and 'foreign practices', such as

9I Acker, Weinland Siebenbürgens, pp. 96, 98.

92 Wolff, Genossenschaftswesen, p. 3.

93 Christian Promitzer, Sevasti Trubeta, and Marius Turda, 'Framing Issues of Health, Hygiene and Eugenics in Southeastern Europe', in Health, Hygiene and Eugenics in Southeastern Europe to I945, ed. by Christian Promitzer, Sevasti Trubeta, and Marius Turda (Budapest, 20II), pp. I-2.

94 Tudor Georgescu, 'The Eugenic Fortress: Alfred Csallner and the Saxon Eugenic Discourse in Interwar Romania', in Health, Hygiene and Eugenics, p. 383. 
modern dance and music. ${ }^{95}$ Condemnations of alcohol consumption were frequently gendered, particularly targeting women. For example, medical doctor and Mediascher Dr Richard Frank, leader of the Templar youth wing, railed against the ills of young women drinking:

It is the done thing, that the 'ladies' in society drink schnapps and smoke cigarettes; the 'gentlemen' also think the mood would be acceptable and 'cozy' only after the second glass. Then a little Shimmy makes the occasion. Our middle-class girls begin to get a taste for the thing. You see it in the 'better' circles, these are the carriers of 'good manners' and teachers of 'modern' trends. Is it any wonder that so many young men rather stay happy bachelors - not to mention the difficult struggle for existence today? Many a girl's eyes open too late. There are also among us too many girls with whom one 'entertains oneself', but who one certainly does not want to marry. One of the most experienced doctors in Hermannstadt [Sibiu/Nagyszeben] wrote but just the other day with much solemnity in the Sächsisches Arzteblatt of the incipient arrival of prostitution in Saxon middle-class circles. ${ }^{96}$

These views were strikingly similar to those of the conservative morality movement in Germany, which also associated alcohol with new forms of mass culture, particularly nightclubs and dance halls in which young drinkers wore the latest fashions, intermingled freely with the opposite sex, and danced licentious dances to the beat of 'alien' music. Moral conservatives condemned these transnational cultural influences as 'American'. These attitudes reflected the rhetoric of moral decline widespread in the Western world and especially Germany in the late nineteenth and early twentieth centuries. ${ }^{97}$ The Transylvanian Templar journal Sonnenwende frequently reprinted articles from German abstinence publications, as did the Evangelischer Fürsorger, the journal of the Welfare Office, which Siegmund edited.

However, abstinence campaigners used moral arguments about alcohol consumption to address local anxieties. While the Good Templars were an international order, Saxons reframed teetotalism in a specifically Saxon context. In theory, the Good Templars offered equal membership regardless of gender or race. However, it permitted members to organize separate lodges on racial or linguistic grounds. ${ }^{98}$ Saxon Good Templars took advantage of this option to form a separate Great Lodge in Mediasch. ${ }^{99}$ Many (though not all) Templars in East Europe did the same. ${ }^{\text {I0o }}$

95 Luise Olah, 'Unser Jugendwerk und seine Arbeit', Sonnenwende, 15 April I927, pp. 3-5.

96 R. E. F[rank], 'In Ketten ...', Sonnenwende, 25 October I928, p. 2.

97 Edward Ross Dickinson, 'The Men's Christian Morality Movement in Germany, I880-I9I4: Some Reflections on Politics, Sex and Sexual Politics', Journal of Modern History, 75 (2003), 60-77; Andrew Lees, 'Deviant Sexuality and other "Sins": The Views of Protestant Conservatives in Imperial Germany', German Studies Review, 23 (2000), 453-67; Detlev J. K. Peukert, The Weimar Republic: The Crisis of Classical Modernity (London, I99I), pp. I64-76; James S. Roberts, 'The Tavern and Politics in the German Labor Movement, c.I870-I9I4', in Drinking: Behavior and Belief in Modern History, ed. by Susanna Barrows and Robin Room (Berkeley, Los Angeles, and Oxford, I99I), pp. I0I-07; James S. Roberts, 'Drink and Industrial Work Discipline in Nineteenth Century Germany', Journal of Social History, I5 (I98I), 25-26.

98 David M. Fahey, 'Blacks, Good Templars and Universal Membership', in The Changing Face of Drink: Substance, Imagery, and Behaviour, ed. by Jack S. Blocker Jr and Cheryl Krasnick Warsh (Ottowa, I997), pp. ${ }^{5}{ }^{8-59}$.

99 Ernst Wagner, 'Heinrich Siegmund und die “volksbiologische” Forschung in der Zwischenkriegzeit', Zeitschrift für siebenbürgische Landeskunde, 6 (1983), I78.

${ }^{100}$ Eisenbach-Stangl, 'Alcohol Policy', p. 7I4; see 'Die sächsischen Guttempler', Kirchliche Blätter, 2 May I929, p. 179 . 
In Western Europe, French and German morality campaigners drew a direct connection between sexual order and threat to the political order. Declining public decency would lead to tyranny and class revolution. ${ }^{\text {IOI }}$ By comparison, although Saxons were over-represented among Romania's few industrial workers, ${ }^{\text {IO2 }}$ many came from a background of skilled artisanry, and were too socially conservative to be attracted by socialism. ${ }^{103}$ The Literati concluded that socialism posed little danger of spreading among the nationally conscious Saxon working class. ${ }^{104}$

Rather, Saxon anxieties stemmed from the community's minority status. For Saxon moral conservatives, the 'immoral' and 'foreign' practices associated with alcohol consumption constituted acculturation, undermining social unity and leading to assimilation and intermarriage. Saxon moral conservatives idealized traditional village life for its social cohesiveness. Communal events such as ritualized folk dances provided carefully regulated contexts in which young Saxons first began courting their future spouses. ${ }^{\text {I05 }}$ Folk costume, worn daily, constituted a visible declaration of one's Saxon ethnicity and Lutheran faith. ${ }^{106}$ Thus, Saxon folk culture segregated Saxons from non-Saxons and discouraged inter-marriage. ${ }^{107}$

By comparison, for Saxon social conservatives, dancing to foreign music in ethnically mixed nightclubs, wearing ethnically indistinct modern fashions, all under the pernicious influence of alcohol, symbolized a lack of commitment to the Saxon community, and an advanced state of acculturation. Furthermore, such interactions brought with it a pronounced risk of miscegenation. ${ }^{108}$ Young women, as future Saxon mothers, thus bore the brunt of anxieties about alcohol consumption and sexual impropriety. Moral conservatives feared such practices would spread from the fashion-setting urban middle classes to the broader population. ${ }^{\text {109 }}$

Racial anxieties reinforced concerns about alcohol's impact on tradition. The Mediasch-based medical doctor Heinrich Siegmund, who stands out as an early adopter of eugenics theories in East Europe, was the leading abstinence campaigner in the first three decades of the twentieth century. ${ }^{\text {IIO }} \mathrm{A}$ racial eugenicist of the

${ }^{\text {ror }}$ Brennan, 'Alcohol in France', pp. 78-79; Dickinson, 'The Men's Christian Morality Movement', pp. 6I, 93.

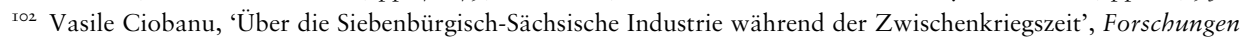
zur Volks- und Landeskunde, 36 (1993), 78.

${ }^{103}$ Glass, Zerbrochene Nachbarschaft, pp. I36, I42.

${ }^{104}$ O. F. Jickeli, 'Kastengegensatz und Klassengefahr bei den Siebenbürger Sachsen', Ostland, I (I926), I07-I2; Emil Neugeboren, 'Eine wirkliche Klassengefahr bei den Siebenbürger Sachsen', Ostland, I (1926), 426-29; see Alfred Hermann, 'Die siebenbürgisch-sächs. Fabriksarbeiterin', in Mädchenbildung und Frauenberufe, ed. by Heinrich Brandsch (Schäßburg, I930), pp. 9I-94.

${ }^{105}$ Schullerus, Volkskunde, pp. I46-58; Boner, Transylvania, pp. 207-08.

${ }^{106}$ Carl Römer, 'Sächsische Volkstracht', in Wehr- und Mehrbuch, pp. 308-ıI.

${ }^{107}$ Friedrich Müller-Langenthal, 'Werden und Wesen des sieb.-sächs. Bauertums', Klingsor, 4 (1927), 94-96; Heinrich Siegmund, 'Aufgaben der sächsischen Rassenpflege', in Wehr- und Mehrbuch, pp. 2I4-I5.

${ }^{108}$ Emil Schneider, 'Jugend von Heute!', Sonnenwende, I5 April 1927, pp. 5-6; 'Volktanz und Schimmi', Sonnenwende, 3 I November I927, pp. 2- 3; M. H., 'Wie sollen wir auf dem Dorfe benehmen?', Sonnenwende, 24 December 1927, pp. 4-6; 'Aus dem "Eulenloch” der Zeit', Sonnenwende, 24 December 1927, p. 6 and 29 February I928, pp. II-I2; Julius Ernst Gyurgyevich, 'Singen', Sonnenwende, 29 February I928, pp. 8-9. See also Sacha E. Davis, 'Maintaining a "German” Home in Southeast Europe: Transylvanian Saxon Nationalism and the Metropolitan Model of the Family, I918-I933', History of the Family, I4 (2009), 386-40I.

${ }^{\text {rog }} \mathrm{F}[\mathrm{rank}]$, 'In Ketten', p. 2.

Iто Marius Turda, Modernism and Eugenics (London, 2010), p. 3 I. 
'Nordic' school and follower of Alfred Ploetz, ${ }^{\text {III }}$ Siegmund worried that interactions with other ethnicities would result in inter-breeding with racially 'inferior' people, diluting the Saxons' 'Nordic' heritage. ${ }^{\text {II2 }}$

German-speaking Good Templars were closely tied to the eugenics movement. ${ }^{\mathrm{II} 3}$ In Transylvania, Siegmund was the founder and Grand Templar of the Great Lodge in Mediasch. ${ }^{\text {II } 4}$ From 1920 to 1937 he was also the founding director of the Lutheran Church's Welfare Office, which reflected his eugenicist vision. Its activities included promoting population increase and improving the wellbeing of future generations, in part by 'combating disease, including the poison of alcohol'. ${ }^{\text {II } 5}$ Many Good Templars sat on local committees of the Welfare Office, giving a degree of Church recognition to the Templars. ${ }^{\text {II } 6}$

Eugenics was both a transnational and a distinctly local phenomenon. ${ }^{\text {II7 }}$ Siegmund followed closely developments in North America and Western Europe; like most eugenicists in South-East Europe he was most strongly influenced by eugenics in Germany and Austria. ${ }^{\text {II } 8}$ However, he ignored the work of the many non-German Eugenicists in East Europe, including the Romanian eugenic movement in Transylvania. This development of Eastern European eugenics movements in parallel, rather than in cooperation with one another is not surprising; as East European eugenicists were engaged in national eugenics, they defined in opposition to one another the subject populations they constructed. By comparison, Siegmund's interest in German eugenics rested not only on a shared language and the long-standing Saxon tradition of looking to the German-speaking lands for cultural influences, but also on a supposed common 'Nordic' heritage. ${ }^{\text {II }}$

To Siegmund, as to the medical profession more broadly at the time, ${ }^{\mathrm{I} 20}$ alcohol was a genetic poison, causing physical and mental defects via 'the damaging of the human germ through poisonous substances' [Keimschädigung durch Keimgift]. ${ }^{\text {I2I }}$ Siegmund believed that drinking of alcohol by parents caused inherent physical and mental

III Sheila Faith-Weiss, 'The Racial Hygiene Movement in Germany, I904-I945', in The Wellborn Science: Eugenics in Germany, France Brazil and Russia, ed. by Mark B. Adams (Oxford, I990), p. Io; Tudor Georgescu, 'Ethnic Minorities and the Eugenic Promise: The Transylvanian Saxon Experiment with National Renewal in Inter-war Romania', European Review of History, I7 (2010), 865.

${ }^{112}$ Heinrich Siegmund, 'Die Rassenmischung', in Wehr- und Mehrbuch, pp. I87-93.

${ }^{13}$ Hasso Spode, Die Macht der Trunkenheit: Kultur- und Sozialgeschichte des Alkohols in Deutschland (Opladen, I993), pp. 220-23.

${ }^{\text {II4 }}$ Wagner, 'Heinrich Siegmund', p. I78: Georgescu, 'Ethnic Minorities', pp. 865-66.

${ }_{115}$ 'ZII76.I92I Rundschreiben betreffend die Einrichtung der Fürsorgeausschüsse', in Kirchliche Blätter, I2 March I92I, pp. 3I-34; Georgescu, 'Eugenic Fortress', pp. 355-56.

${ }^{\text {II6 }}$ 'Z.2375.192I behufs Mithilfe an der Arbeit der evang. Wohlfahrts- und Gesundheitspflege', Kirchliche Blätter, II June I92I, p. 74; 'Z.2304.I92I. Rundschreiben betreffend die Arbeitsanleitung für die Fürsorgestellen der Presbyterien', Kirchliche Blätter, 26 November I92I, pp. 190-91.

${ }^{\text {II7 }}$ Promitzer el al., 'Framing Issues of Health, Hygiene and Eugenics', pp. I6-I7.

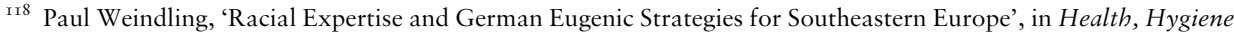
and Eugenics, pp. $40-46$.

II Siegmund's most significant works were Siegmund, ed., Wehr- und Mehrbuch (1914/22), Heinrich Siegmund, Deutschen-Dämmerung in Siebenbürgen (Verdrängen oder Vernichtung?) (Hermannstadt, I93I) and the Evangelischer Fürsorger, journal of the Church's Welfare Office.

I20 Spode, Macht der Trunkenheit, pp. I35-38.

${ }^{\text {I2I }}$ H.S., 'Fürsorge und Vererbung', Kirchliche Blätter, I2 February I925, pp. 75-76. 
defects in children, particularly 'feeble-mindedness' [Schwachsinn], a catch-all phrase including foetal alcohol syndrome: ${ }^{\text {222 }}$

A people whose race, whose blood degenerates is not viable, but alcohol is a racial poison, is a pacesetter of diseases (sexually transmitted diseases, tuberculosis), and promotes mental illness and suicide. The drinker harms himself, his children and grandchildren. ${ }^{\mathrm{I} 3}$

Abstinence advocates also condemned alcohol consumption as a financial waste. While female drinkers were castigated for sexual impropriety, abstinence advocates condemned male drinkers for undermining their ability to support their families and thus hindering the community's demographic growth. For example, Frank worried that young male drinkers would remain playboys, rather than engaging in the economic struggle to support a family. ${ }^{\mathrm{I} 24} \mathrm{~A}$ report from a local welfare committee in I927 condemned young male drinkers for the financial and health impacts of their behaviour: 'some young men increasingly submit to this evil and run the risk of diminishing possessions and weakening the body'. ${ }^{125}$ Reinforcing traditional gender roles, another welfare committee worried about the impact of such actions on dependants: 'How could the children be able to live a carefree life, when the weakwilled, contaminated father pushes them out into the unknown, where one thousand hardships and dangers await them'. ${ }^{\text {I26 }}$

Like Saxon economists, abstinence campaigners framed economic loss in particularist terms, as a threat to the Saxon community. However, to Siegmund, the financial waste caused by alcohol consumption also threatened the Saxons with extinction. A Malthusian, Siegmund was anxious to maintain the highest possible Saxon population growth, which he considered to be limited by the size of Saxon landholdings (and the efficiency with which that land was exploited). ${ }^{127}$ Siegmund first advanced his 'Displacement Theory' in I90I. While the Saxon population was growing in absolute terms, its rate of increase was declining and had fallen behind that of Romanians and Hungarians. Siegmund calculated that, in the aftermath of demographic disasters such as wars or plagues, Saxons would recover more slowly than other Transylvanian communities. As a result, non-Saxons would be able to occupy formerly Saxon-owned land before Saxons had recovered sufficiently to reclaim it, thereby progressively reducing Saxon landholdings after each disaster (and with it, reducing the maximum possible Saxon population size). If unchecked, this process would ultimately result in the extinction of the Saxons. Alcohol compounded the problem, Siegmund argued, by reducing Saxon wealth and the birth rate. ${ }^{\mathrm{I} 28}$

Internationally, anti-alcohol campaigners were divided between those who advocated temperance and those who insisted on complete abstinence. Anti-alcohol campaigners in countries with strong wine-making traditions such as France frequently

\footnotetext{
${ }^{122}$ H. Siegmund, 'Die Fürsorgearbeit in unseren Gemeinden', Kirchliche Blätter, I2 January I922, p. Iо.

${ }^{123}$ Heinrich Siegmund, 'Die Weingeistfrage in Sprüchen', in Wehr- und Mehrbuch, p. I46.

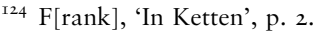

${ }^{125}$ H. Siegmund, 'Bericht über den Stand der Fürsorge im Jahre I927', Evangelischer Fürsorger, II/I2 (I928) Kirchliche Blätter, 27 December I928, p. 47.

${ }^{126}$ Ibid., p. 47.

I27 Wagner, 'Heinrich Siegmund', pp. I8I-84.

${ }^{228}$ Ibid.; Georgescu, 'Eugenic Fortress', pp. 354-55; Siegmund, Deutschen-Dämmerung.
} 
advocated temperance rather than abstinence. ${ }^{\text {I29 }}$ Likewise, East European eugenics societies tended to oppose alcoholism rather than alcohol. ${ }^{130}$ In Romania, temperance campaigners actually advocated the consumption of wine in moderation as a lower alcohol substitute to hard spirits. ${ }^{\text {I3I }}$ Unusually, Saxon campaigners insisted on complete abstinence, despite the economic and symbolic importance ascribed to wine. For example, delegates at a Saxon women's conference in 1922 asserted that even the smallest quantities of alcohol were harmful, and that it was not a matter of individual health but of the health of the entire Volk. ${ }^{\mathrm{I} 2}$

Siegmund's preferred solution to alcohol was complete prohibition. ${ }^{\mathrm{I} 33}$ However, even if Saxon abstinence campaigners had managed to secure majority support in their own community, they had little ability to influence Romanian politics. ${ }^{\mathrm{I} 4}$ Powerless to influence state alcohol laws, they relied on persuasion to change Saxon drinking practices.

Siegmund and many other Saxon abstinence campaigners targeted viniculture above other forms of alcohol production even though, according to his own calculations, wine accounted for less than I2\% of ethanol consumed by Saxons, as opposed to nearly $77 \%$ from spirits. Two factors drove Siegmund's preoccupation with wine. Firstly, he believed that the viniculture industry, as well as wine consumption, harmed Saxons financially. Siegmund dismissed claims that viniculture offered a solution to the economic plight of the peasantry. He characterized the relationship between wine merchants and growers as akin to that between master and slave, bringing merchants profit and droving growers into debt. Furthermore, he argued, viniculture was financially harmful to the Saxon community as a whole, especially if one included loss of potential income from the sale of grape sugar and from alternative crops not sown, as well as Saxon expenditure on wine and the harmful impact of its consumption. However, Siegmund did not campaign against grape growing as a whole. Rather, he urged Saxons to forego wine in favour of grapes and sterilized grape juice: ${ }^{135}$

The profitability of grape growing is not endangered by the alcohol free lifestyle. The production of alcohol destroys valuable nutrients. The grape is the best fruit easy to use. Sterilized, the grape and fruit must keeps well, are nutritious and very tasty [...] Not Wineland [Weinland], but Grapeland! ${ }^{136}$

Other campaigners adopted Siegmund's argument. Good Templar Gustav Conrad urged that grapes be consumed as fruit or grape juice, rather than as wine, ${ }^{\mathrm{I}}{ }^{37}$ while

\footnotetext{
I29 Brennan, 'Alcohol in France', p. 8I.

${ }^{\text {I30 }}$ For example, see Vassiliki Theodurou and Despina Karakatsani, 'Eugenics and Puericulture: Medical Attempts to Improve the Biological Capital in Interwar Greece', in Health, Hygiene and Eugenics, pp. 3I 5-2I; Željko Dugec, "Like Yeast in Fermentation”: Public Health in Interwar Yugoslavia', in Health, Hygiene and Eugenics, pp. 213-19; Marius Turda, 'Controlling the National Body: Ideas of Racial Purification in Romania, I918-1944', in Health, Hygiene and Eugenics, pp. 394-97.

I3I Tămaş, 'Alcoholism', p. II4.

${ }^{132}$ 'Heltauer Vorträge für Frauen', in Kirchliche Blätter, II May I922, p. I45.

${ }^{133}$ H. Siegmund, 'Das Weingeistverbot in den Vereinigten Staaten', in Evangelischer Fürsorger 7 (1929)/Kirchliche Blätter, I August I929, pp. 26-27.

I34 'Unsere Guttempler an der Arbeit', Kirchliche Blätter, Iо January 1924, p. II.

${ }^{135}$ Heinrich Siegmund, 'Hindert uns der Weinbau', pp. I55-6I.

${ }^{136}$ Siegmund, 'Weingeistfrage', p. I48.

${ }^{137}$ G. Conrad, 'Begeisterung und Tat', Jugendbundblatt, October-November I925, pp. 3-4.
} 
attendees of the 1922 Saxon women's conference argued that, rather than doing economic harm, making a country dry provided new opportunities for table grapes and grape juice. ${ }^{\mathrm{I} 38}$

Secondly, by targeting Saxon viniculture as distinct from the broader wine industry, and from the alcohol industry in general, Siegmund and his followers delineated a sphere of activity that Saxons could conceivably control by swaying popular opinion in their own community. This sense of agency was illusionary; Saxons were far from the only wine producers in the region, and consumed other alcoholic beverages. Siegmund ignored the possibility that, if Saxons stopped producing wine, they would simply purchase Romanian- or Hungarian-grown wine, or increase their consumption of industrially produced spirits.

Abstinence campaigners had a number of avenues for publicizing their views. Siegmund was a prolific author, producing more than a thousand publications in his lifetime, many of which advocated abstinence. ${ }^{\mathrm{I}}{ }^{39}$ Good Templar journals were one outlet for his and other campaigners' views, as well as reprinting material from Germany. However, the Good Templars had a small and static membership; at the end of I923, there were 'hundreds' of Good Templars in Transylvania, and three hundred Juvenile Templars in Mediasch. ${ }^{\mathrm{I} 40}$ By 1929, there were still only 398 adult members and $3 \mathrm{I} 8$ youth members in German lodges in Transylvania. ${ }^{\mathrm{I}}{ }^{\mathrm{I}}$ Above all, the abstinence movement relied on the Church to disseminate their ideas. Saxon eugenics campaigners looked to the Church as an ersatz state through which to carry out their programme. ${ }^{\mathrm{I} 2}$ The Church sponsored the Welfare Office that Siegmund led, and distributed the Office's journal, the Evangelischer Fürsorger with its own monthly journal, the Kirchliche Blätter. Like Schullerus's ethnographies, Siegmund's public health tracts became standard teaching material in Church schools from primary schools through to teaching seminaries, and in the Church's continuing education classes.

However, anti-alcohol messages made little headway. The economic arguments of abstinence campaigners failed to curb wine production. Much of Transylvania's vine stock was grown on land that could not be profitably used for other purposes, and viticulture provided a small income for those able to farm it with unpaid labour. Table grapes and fruit juice did not provide a viable alternative. A report from one village in the Weinland to the Church's Welfare Office in I927 captured the barriers that would need to be overcome:

the production of wine represents a question of life for the people since the community draws its greatest profit - up to 7 million annually — from the sale of wine, the sale of grapes is possible only in vanishing proportions due to its remoteness from the marketplace, and the production of grape juice $[S \ddot{u} \beta$ most $]$ in our circumstances does not seem possible.

Although the Agronomics Association recommended several table grape varieties for cultivation, the interwar fruit market was at least as depressed as the wine market. ${ }^{\mathrm{I} 33}$

\footnotetext{
${ }_{13} 8$ 'Heltauer Vorträge für Frauen', p. I45.

139 Wagner, 'Heinrich Siegmund', p. I79.

${ }^{140}$ 'Wie man im Mutterland über uns urteilt', Jugendbundblatt, November I923, p. 7.

I4I 'Die sächsischen Guttempler', I79.

${ }^{\text {I42 }}$ Georgescu, 'Ethnic Minorities', 686.

I43 Acker, 'Weinbau', pp. 82-98; Acker, Weinland Siebenbürgens, pp. 76-79.
} 
Campaigns to alter Saxons' leisure practices and consumption of alcohol were equally unsuccessful. The strict morality of the Templars limited their mass appeal, for example isolating its youth section from other Saxon youth organizations. ${ }^{\text {I } 44}$ In some cases, the Templars may have exerted an influence on non-members to abstaining from alcohol. ${ }^{45}$ Even so, abstinence campaigners' appeals were ineffectual in curbing alcohol consumption. Reports to the Welfare Office revealed an entrenched, widespread drinking culture that the economic downturn of the late I92os did little to reduce. ${ }^{\mathrm{I} 6}$ Reports of rampant alcoholism may have reflected moral panic rather than actual drinking levels. ${ }^{\mathrm{I} 7}$ However, it is clear that alcohol remained a popular intoxicant.

In 1930 the Church introduced alcohol- and tobacco-free Sundays. Congregants were expected to donate to charity the money thus saved to the Land Protection Fund [Bodenschutzfund], founded to help impoverished Saxons retain or increase their landholdings. While the charity thus reflected Siegmund's eugenicist concerns about the impact of alcohol and land loss, the motive for Church support may have been primarily charitable. By I930 Transylvania was in the grips of the Great Depression, agricultural debt was mounting, and many farmers faced ruin. However, alcohol-free Sundays were unpopular and there is little evidence that the measure was widely observed. ${ }^{148}$ Indeed, the Church tempered its support for the abstinence movement with an appreciation of economic realities; its continuing education classes also included lessons in viniculture. ${ }^{\mathrm{I} 49}$

Anti-alcohol tracts had a greater impact on Saxon particularism than drinking practices. By couching their anti-alcohol campaign in ethnic and racial terms, abstinence advocates reinforced the Saxons' separate status and sense of cultural and racial superiority. At the same time, they greatly raised fears that Saxons faced irreversible moral and racial decline. This modernist, eugenicist understanding of Saxonness helped lay the intellectual foundations for the spread of fascism in the Saxon community. Siegmund's ideas about alcohol, as part of his broader writings on race and degeneration eased the way for self-styled National Socialists to seize control of the Saxon political apparatus in $1933 .{ }^{150}$ Although Siegmund never held office, Saxon fascists treated him as an elder statesman of the movement. ${ }^{\text {I5I }}$

${ }^{144}$ [Friedrich] Cz[ikeli], 'Ueber unsere Tagung', Jugendbundblatt, July 1924, p. 7; Friedrich Czikeli, 'Aus dem Bericht des Schriftleiters über das Jugendbundblatt', Jugendbundblatt, Io October 1928, pp. I02-04.

I45 'Bericht über den Stand der Fürsorge im Jahre 1929', Evangelischer Fürsorger, I2 (I93I)/Kirchliche Blätter, 3 I December I93I, p. 45.

${ }^{146}$ 'Bericht über den Stand der Fürsorge im Jahre 1926', Evangelischer Fürsorger, 9 (1927)/Kirchliche Blätter, I3 October I927, p. 22.

I47 Brennan, 'Alcohol in France', pp. 74-75.

${ }^{\text {I }} 88$ Wagner, 'Heinrich Siegmund', p. I78; 'Z.54II/1930 Bekämpfung der Weingeist- und Tabaksgenüsse und Einführung Weingeist- und Tabakfreier Sonntage', Kirchliche Blätter (I930), p. 525; 'Z.I348/I93I Durchführung des Rundschreibens über Bekämpfung der Weingeist- und Tabaksgenüsse und Einführung Weingeist- und Tabakfreier Sonntage', Kirchliche Blätter (1931), p. I95.

I49 'Richtlinien zu einem Arbeitsplan für die Fortbildung der konfirmierten Jugend', Supplement to Kirchliche Blätter, I4 October 1926.

${ }^{150}$ Robert O. Paxton, The Anatomy of Fascism (London, 2004), pp. 24-42; Davis, 'Maintaining a "German" Home', p. 398; Georgescu, 'Ethnic Minorities'.

${ }^{151}$ Julius Ernst Gyurgyevich, Landeskonsistorialrat Dr. Heinrich Siegmund, Stadtoberarzt d. R. I867-I937 (SibiuHermannstadt, I937). 
Saxon Nazis were no more able to resolve the irreconcilable attitudes to wine than had been previous community leaders. As in Germany, fascist leaders were caught between the desire to reduce the perceived financial and biological cost of alcohol consumption, and the need to support the wine industry to maintain employment. ${ }^{152}$ Through the 'Ethnic Group of Germans in Romania' (Volksgruppe der Deutschen in Rumänien), the peak political body established by Saxon National Socialists, the eugenicist and pastor Alfred Csallner continued the campaign against alcohol after Siegmund's death. Csallner concentrated primarily on the economic harm alcohol caused, rather than on its direct impact on health. ${ }^{153}$ However, the Ethnic Group of Germans in Romania also established a Transylvanian Farmers' Office to encourage agricultural development; from 1940 the vintner and future wine historian Hans Acker (I9I3-) was its leader. ${ }^{\text {I54 }}$ Under Acker, the Farmers' Office organized wine exhibitions and fostered the continued development of Saxon viniculture in various ways. ${ }^{155}$ Tensions over competing views of wine remained insoluble, and were superseded only following the communist takeover of Romania in 1945 , which ushered in a very different model of modernization.

\section{Conclusion}

The sweeping changes Saxons faced between I860 and I930 impacted on most aspects of life. Many economic sectors faced increased competition and need for reform, which in turn threatened the survival of traditional practices. Alcohol consumption was far from the only unnecessary form of expenditure or deleterious impact on the health of Saxons. However, viniculture and wine consumption provide particularly interesting insights into Saxon responses to modernization because of the conflicting symbolic functions they performed, simultaneously embodying the community's historical roots, aspirations for a more prosperous future, and threats to the community's survival.

Through viniculture and wine, the Literati exercised a measure of control over some of the modernizing influences they faced. Appeals to the Saxon civilizing mission through viniculture proved ineffectual at compensating for lack of control over the Weinland or exercising influence within the exclusivist nation-state. However, through writings on viniculture, Saxon ethnographers reinforced Saxon particularism and a sense of entitlement to territory. Economists were unable to overcome the depressed wine market and develop a vibrant modern viniculture industry. Although cooperatives were popular, viniculture was not the basis of their success. Nonetheless, they allowed viniculture to modernize sufficiently to survive as a modest supplement to Saxon farmers' incomes. Abstinence advocates appear to have been least successful in implementing their policies. However accurate Siegmund's negative assessment of the existing viniculture industry may have been, table grapes and grape juice did not provide a commercially viable alternative. Focusing on Saxon viniculture was an

\footnotetext{
${ }^{152}$ Hermann Fahrenkrug, 'Alcohol and the State in Nazi Germany, I933-1945', in Drinking, pp. 317-20.

${ }^{153}$ Georgescu, 'Eugenic Fortess', p. 377.

${ }^{154}$ Klaus Popa, Völkisches Handbuch Südosteuropa (20I2), <http://www.zinnenwarte.de/Transsylvania/A.pdf> [accessed 28 January 20I3].

${ }^{155}$ Acker, Weinland Siebenbürgens, p. 98.
} 
ineffective means of influencing Saxon consumption of alcohol, which by Siegmund's own calculations came mostly from other sources. Nor were moral conservatives able to combat Saxon drinking habits, or the new cultural practices that came with them; the Good Templars remained a small organization with only local appeal, unable to compensate for the lack of state powers to impose prohibition. However, Siegmund's abstinence tracts reinforced notions of a Saxon community that was racially defined, and mortally imperilled, smoothing the path to power of the radical right.

While the Literati were able in many instances to utilize or ameliorate the impact of transnational developments, they were ultimately unable to overcome the limitations inherent in forming a small minority community. Their aspirations frequently ran counter to one another. Even so, they played crucial roles in the modernization process within the Saxon community. Ethnographers, economists, and eugenicists all appealed to tradition to legitimize their programmes. However, the interpretations they made of the challenges the Saxons faced were as modern as the transformative processes to which they responded.

\section{Notes on contributor}

Sacha Davis lectures in history at the School of Humanities at the University of Newcastle, New South Wales, Australia.

Corresponence to: Sacha Davis. Email: sacha.davis@newcastle.edu.au 